\title{
A review of landslide acceptable risk and tolerable risk
}

\author{
Kwan Ben Sim, Min Lee Lee ${ }^{*}$ (i) and Soon Yee Wong
}

\begin{abstract}
Landslides are one of the most important geohazards. In 2004-2016, more than 55,000 people lost their lives to landslides and this does not include deaths caused by seismically triggered landslides. Overall losses were estimated to be at USD 20 billion annually. The lives of many could be saved if more had been known regarding forecasting and mitigation. Studies have shown an increasing trend in landslides occurrence and fatalities. Over recent years, landslide risk assessment has been carried out extensively by geo-scientists worldwide. This review concentrates on the societal risks posed by landslides in various countries and the risk criteria used by various parts of the world in assessing landslide risks. The landslide risk tolerance criteria are strongly governed by utilitarian concerns i.e. financial power and the need for development. In developing countries, surprisingly high levels of tolerance are proposed for landslides. The risk criteria of Hong Kong and that of the Australian Geomechanics Society are widely employed in many countries. Although various risk tolerance levels have been proposed by various nations, many of them are still not being applied in their real-life scenarios. The procedures for setting risk criteria call for a wide agreement between geoscientists, government decision makers, and the community. Risk criteria should be developed locally with historical landslide inventory, public perception, and engineering aspects being considered.
\end{abstract}

Keywords: Landslide, Tolerable risk, Acceptable risk, Societal risk, Frequency-number of fatalities diagram

\section{Introduction}

Landslides are one of the major devastating geohazards and claim thousands of lives and create acute economic losses related to property damage every year (Schuster and Highland 2001; Dilley et al. 2005; Petley 2012). Centuries prior, many countries worldwide have suffered deaths and economic losses due to landslides and the impact is still on the rise. The first documented landslide was an earthquake induced landslide dam in Honan Province of China in the year 1767 B.C. (Schuster 1996). International Disaster Database (EM-DAT) of the Centre for Research on the Epidemiology of Disasters reported that landslides caused $17 \%$ of the deaths associated with natural hazards worldwide annually (Lacasse and Nadim 2014; Aristizábal and Sánchez 2020). Landslides not only

\footnotetext{
*Correspondence: minlee.lee@nottingham.edu.my

Department of Civil Engineering, Faculty of Science and Engineering, University of Nottingham Malaysia, 43500 Semenyih, Selangor, Malaysia
}

result in casualties to both humans and animals but disrupt the water quality of streams and rivers as well as the destruction of structural and infrastructural developments. Of the total loss of life resulting from natural hazards worldwide, $5 \%$ of it comes from highly developed nations. The remaining $95 \%$ of total deaths are from medium and developing countries (Lacasse et al. 2010; Lacasse and Nadim 2014). Klose et al. (2015) reported that the economic impact of landslides is likely the greatest on transportation infrastructures. This is especially true in rural regions where the transportation network is scattered, and the availability of alternate routes is few to none. As a result, a minor landslide will bring a great impact on the economic sector over an extensive region (Winter et al. 2018). According to Dowling and Santi (2014), landslides are catastrophes resulting from social vulnerability.

Socioeconomic impacts of landslides are always underestimated because landslides in many countries are
Springer Open

(c) The Author(s) 2022. Open Access This article is licensed under a Creative Commons Attribution 4.0 International License, which permits use, sharing, adaptation, distribution and reproduction in any medium or format, as long as you give appropriate credit to the original author(s) and the source, provide a link to the Creative Commons licence, and indicate if changes were made. The images or other third party material in this article are included in the article's Creative Commons licence, unless indicated otherwise in a credit line to the material. If material is not included in the article's Creative Commons licence and your intended use is not permitted by statutory regulation or exceeds the permitted use, you will need to obtain permission directly from the copyright holder. To view a copy of this licence, visit http://creativecommons.org/licenses/by/4.0/. 
always taken as a consequence arising from other triggering processes such as extreme precipitation, typhoons, volcano eruptions or earthquakes. The damage costs from landslides could surpass all other costs from the overall multiple-hazard catastrophes (Froude and Petley 2018; Sultana 2020). Studies have indicated that the EM-DAT database often underestimates the number of fatal landslides by $1400 \%$ (Kirschbaum et al. 2015) or $2000 \%$ (Petley 2012), and the number of deaths by $331 \%$ (Kirschbaum et al. 2015) or 430\% (Petley 2012). The under-reporting is caused by the perception of landslides as a secondary hazard, in which the cause of death is normally reported in relation to the primary hazards (e.g. an earthquake rather than a seismically triggered landslide) instead of the actual cause of the loss (Froude and Petley 2018). Furthermore, conducting a quantitative economic analysis of landslides is often handicapped by an incomplete landslide database (Winter et al. 2018). As stated by Winter et al. (2019), landslides disrupt access to remote rural regions where the economic activities are typically transport-dependent. Extensive areal vulnerability can be attributed to the transport network instead of the event itself. For example, a landslide event that occurred at an access road in the Blue Mountains of Jamaica completely cut off the nearest route linking local coffee manufacturers with the international market (Winter et al. 2018, 2019). A long-term impact following that event would be on the tourism industry, as well as other economic activities. However, estimations of these long-term losses are challenging as they are typically widely spread out both socially and geographically. This underestimation brings about a lower awareness and appreciation regarding landslide risks among regulators, authorities, and the general public.

In the new millennium, landslides have claimed tens of thousands of lives and an estimated annual average of economic losses of $\$ 20$ billion, which is $17 \%$ of the total (\$121 billion) yearly mean global disaster losses from 1980-2013 (Klose et al. 2016). The average economic losses of various nations caused by landslides worldwide are reviewed in the present study and summarized in Table 1 . To determine the economic losses, government authorities and land-use planners often distinguish between direct and indirect costs. Direct costs comprise of damages directly related to the destruction resulting from the landslide as well as costs for investigation, monitoring, and remedial works to lower the risk. All other costs are indirect and are generally not available. However, those that have been estimated in studies and reports, their values are included in the total costs. It is clear from Table 1 that Japan and Italy suffered the greatest economic loss caused by landslides among the developed countries. The economic costs in these mountainous regions are attributed to their high population

Table 1 Estimated average annual cost of landslide of different countries

\begin{tabular}{|c|c|c|c|}
\hline Country & $\begin{array}{l}\text { Average Annual Direct Costs } \\
\text { (USD) }\end{array}$ & Average Annual Total Costs (USD) & Comments \\
\hline Canada $^{a}$ & - & $\$ 70$ million-1.4 billion & \\
\hline Japan & $\$ 1.5$ billion & $\$ 4$ billion & \\
\hline Korea & $\$ 60$ million & - & Based on poor record \\
\hline Italy & - & $\$ 2.6-5$ billion & Rough Estimate \\
\hline Sweden & $\$ 10-20$ million & - & \\
\hline Spain & $\$ 0.2$ billion & - & \\
\hline Former USSR & $\$ 0.5$ billion & - & \\
\hline New Zealand & & $\$ 26.3$ million & $90 \%$ of costs are sustained in rural areas \\
\hline Belgium ${ }^{b}$ & $\$ 0.85$ million & \$4.48 million & \\
\hline Germany ${ }^{c}$ & $\$ 0.3$ billion & - & \\
\hline India & $\$ 1.3$ billion & & \\
\hline China & $\$ 0.5$ billion & - & Costs based on valuations in 1989 \\
\hline Nepal & \$19.6 million & - & Includes flood damage, but likely incomplete \\
\hline Brazil $^{d}$ & $\$ 45$ million & $\$ 0.35$ billion & \\
\hline Worldwide & & $\$ 20$ billion & \\
\hline
\end{tabular}

The rest of the data were extracted from Sidle and Ochiai (2006)

${ }^{a}$ Cruden et al. (1989), Schuster and Highland (2001) and Sidle and Ochiai (2006)

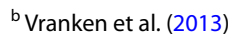

c Klose et al. (2015)

d Batista et al. (2019) 
densities. Considering the lower property values in developing countries such as China, India, and the Himalayas, the economic costs in these mountainous regions are significantly lower. The majority of the landslides in nations such as Nepal, New Zealand, and Canada have their landslide damage occurring in rural areas; and hence the associated costs are comparably lower. Landslide costs in the Scandinavian regions are trivial compared to mountainous topography in the rest of the European continent. The cumulative landslide costs in Europe are lower than in the United States.

From 2004 to 2016, 4862 landslide events have been reported with fatalities exceeding 55,000 (Froude and Petley 2018). Studies have also identified a number of landslide clusters, most notably in the tropical regions such as the Caribbean, Central, and South America, and parts of South and Southeast Asia (Petley 2012; Froude and Petley 2018). Tropical climate countries suffered the greatest loss of lives caused by landslides due to the destabilizing effects of rising groundwater table and loss of suction under extreme downpours (Turner 2018). For example, rainfall-induced landslides in Brazil have killed an excess of 2700 people in 1966 and 1967 (Jones 1974). Additionally, multiple debris flows were driven by several days of torrential downpours that claimed 30,000 lives in Caraballeda, the north coast of Venezuela in December 1999. Figure 1 classifies the landslide triggering factors worldwide. It was further stated by Lacasse and Nadim (2014) that heavy rainfall is the main trigger for mudflows, the most lethal and destructive of all types of landslides. Rainfall-induced landslides were reported to have resulted in nearly $90 \%$ of deaths worldwide (Haque et al. 2016; Sultana 2020).

It is no surprise that landslide disasters will increase significantly as time pass due to global warming and

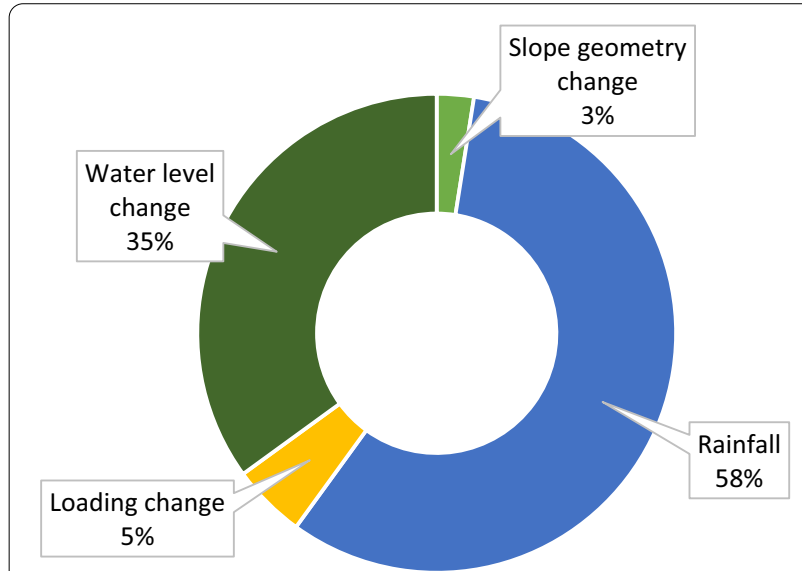

Fig. 1 Distribution of landslide triggering factors around the world (Ng 2012) climate change which have resulted in an increase in precipitation, variations in the hydrological cycle, extreme weather, short-duration heavy downpours (storms), melting of ice in the Alps, and other meteorological events, and coastal erosion due to sea storms (Lacasse and Nadim 2014). An increasing trend was observed in fatalities and occurrence of fatal landslides worldwide in numerous studies published (Petley 2012; Aristizábal and Sánchez 2020; Görüm and Fidan 2021). For example, a rising trend in death toll by landslide disasters was reported in China with the increase of average annual death toll by about $78 \%$ from 1950 to 1999 (Lin and Wang 2018). The numbers of deaths owing to landslides reported on the African continent, however, remain low, i.e. 13 in 2007 (Kjekstad and Highland 2009) and 43 in 2020 (European Commission 2021). This implies a likely severe underreporting as the number of people exposed to landslide hazards there is tremendously high (Kjekstad and Highland 2009). The severe underreporting is mainly caused by the remoteness of the regions and the scarcity of systematic records (Monsieurs et al. 2017). As such, the actual total losses caused by landslides worldwide could be far exceeding the reported statistics.

The emergence of landslide hazard and risk issues, the obligation to look after the society and properties, expected climate change which will further aggravate the landslide situation, and the harsh reality for the public to live with landslide risk have led to requirements for professionals to carry out Quantitative Risk Assessments (QRA). Unless risks are reduced, landslide disasters will continue to rise (Dilley et al. 2005). The Geotechnical Engineering Office (GEO) of the Civil Engineering and Development Department (CEDD), Hong Kong are among the pioneers in implementing the risk-informed approach in landslide assessment. Since the establishment of this approach by the GEO, the overall landslide risk related to man-made slopes in Hong Kong has been lowered significantly by $75 \%$ (Chiu 2015). Since then, the approach had been adopted by several developed western countries such as the UK (Winter and Wong 2020), the Netherlands (Hungr et al. 2016), Australia (Leventhal and Withycombe 2009), and Canada (Hungr 2016; Porter et al. 2017; Strouth and McDougall 2020). Lin and Wang (2018) reported that China has invested heavily in geological disaster control and prevention in recent years, i.e. an increase in allocation from Chinese RMB 330 million in 2000 to 17.6 billion in 2015. As the result, a lower death toll (by about 10\%) by landslides was reported in the 2010s. The United Nations Sendai Framework for Disaster Risk Reduction (2015-2030) has also outlined seven clear targets and four priorities for action to prevent new and reduce existing disaster risks (UNISDR 2015). These efforts showed that landslides have received 
increasing attention globally owing to their high frequency and severity of occurrences in recent decades.

In recent decades, QRA has been studied extensively and numerous guidelines have been published (Geotechnical Engineering Office 1999; AGS 2000, 2007; Wong et al. 2006; Lee and Jones 2014). The flow chart for QRA from Hungr (2016) is shown in Fig. 2. The QRA consists of two stages: Stage 1, Hazard assessment, and Stage 2, Risk assessment. Hazard assessment comprises geo-scientific works such as investigation and analysis to determine and quantitatively define the probable landslide hazards. Hazard is defined as the potential occurrence of a natural or human-induced physical event that may cause loss of life, injury, or other health impacts, as well as damage and loss to property, infrastructure, livelihoods, service provision, and environmental resources (Bobrowsky and Couture 2014). A hazard should be identified and characterized in the first place before its features i.e. magnitude, probability, regional extent, and intensity can be determined. The estimated intensity and its probability of occurrence can then be quantified and mapped into the region of study.

Risk assessment starts with determination of elements at risk which could be humans, infrastructures, buildings or environmental values. They could be existing ones or those in planning for future construction in the area of study. Estimation of risk comes from an intersection of hazard intensity map with the map of elements at risk, in space and time considering vulnerabilities. The Stage 2 is completed with the determination of acceptable risk and designation of mitigation measures. However, the determination of acceptable risks proves to be one of the most challenging aspects of QRA. To mitigate this challenge, it is recommended to use the $F-N$ curve for the region of interest which is a plot showing the number of fatalities $(N)$ plotted against the cumulative frequency $(F)$ of $\mathrm{N}$ on a log-log scale (Dai et al. 2002; Song et al. 2007; Hungr et al. 2016). To be made simpler, the $F-N$ Curve compares the number of fatalities $(\mathrm{N})$ of a landslide event with the probability (or frequency) of that event (F).

Numerous review studies on quantitative risk assessment of landslides can be found from the currently available literature. However, review studies on landslide acceptable risk and tolerable risk as well as $F-N$ Curves are scarce despite substantial works having been reported by researchers from different parts of the world. This paper aims to review the $F-N$ curves reported from various countries. The $F-N$ curves collected deal exclusively with risks to life which is normally the governing factor of landslide disasters (Hungr et al. 2016). Landslide risk acceptance criteria from various nations will also be discussed and reviewed. The findings reported herein can serve as a useful reference for developing the landslide acceptable risk and tolerable risk for a nation.

\section{F-N curve for landslide Introduction to $\mathrm{F}-\mathrm{N}$ curve}

An $F-N$ curve consists of a series of data points that denote each scenario analyzed. It is a combination of scenarios into a single curve that defines the probability (or frequency) of " $N$ or more" fatalities of the complete dataset (Strouth and McDougall 2021). It should be noted that the label $(N)$ can also be represented by other quantities of a consequence such as monetary loss. Such curves could be utilized to demonstrate societal risk (Vrijling and van Gelder 1997; Saw et al. 2009; Strouth and McDougall 2021) and to define the safety levels of the region of interest. It is crucial to be clear that the $F-N$ curves only provide statistical readings and not the threshold of risk acceptance and tolerance. Figure 3

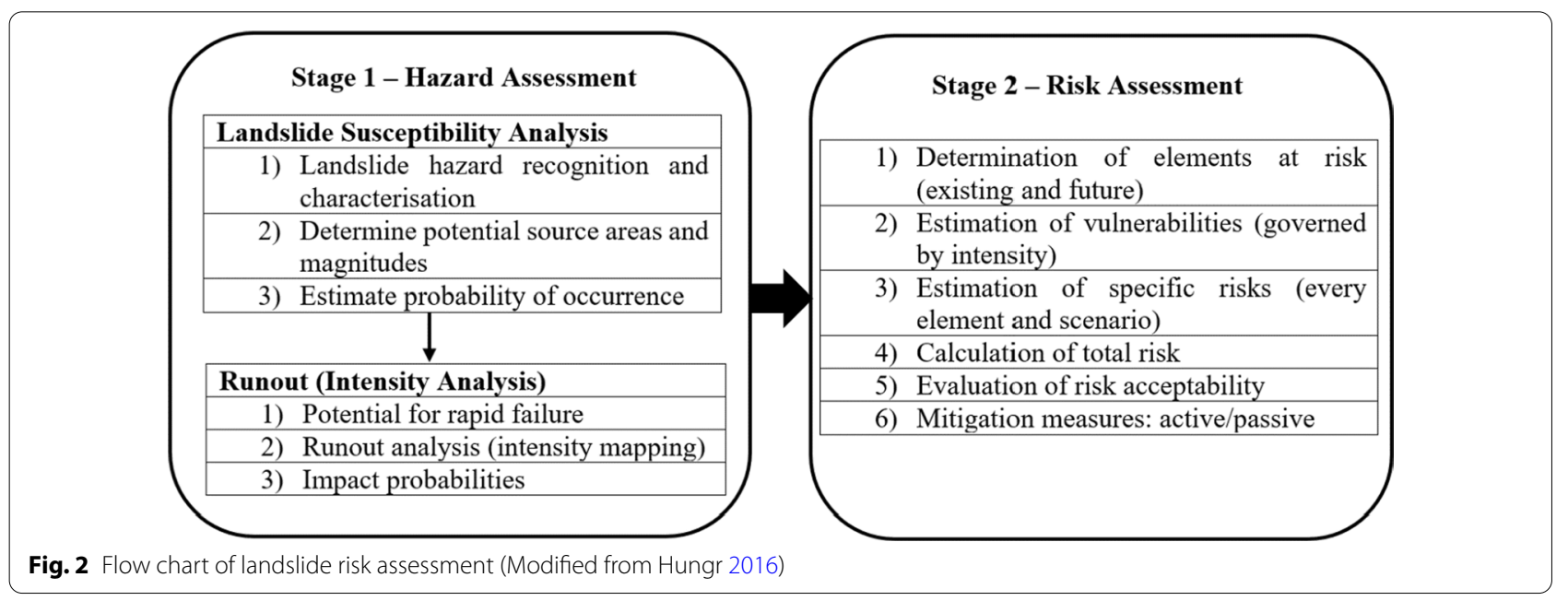



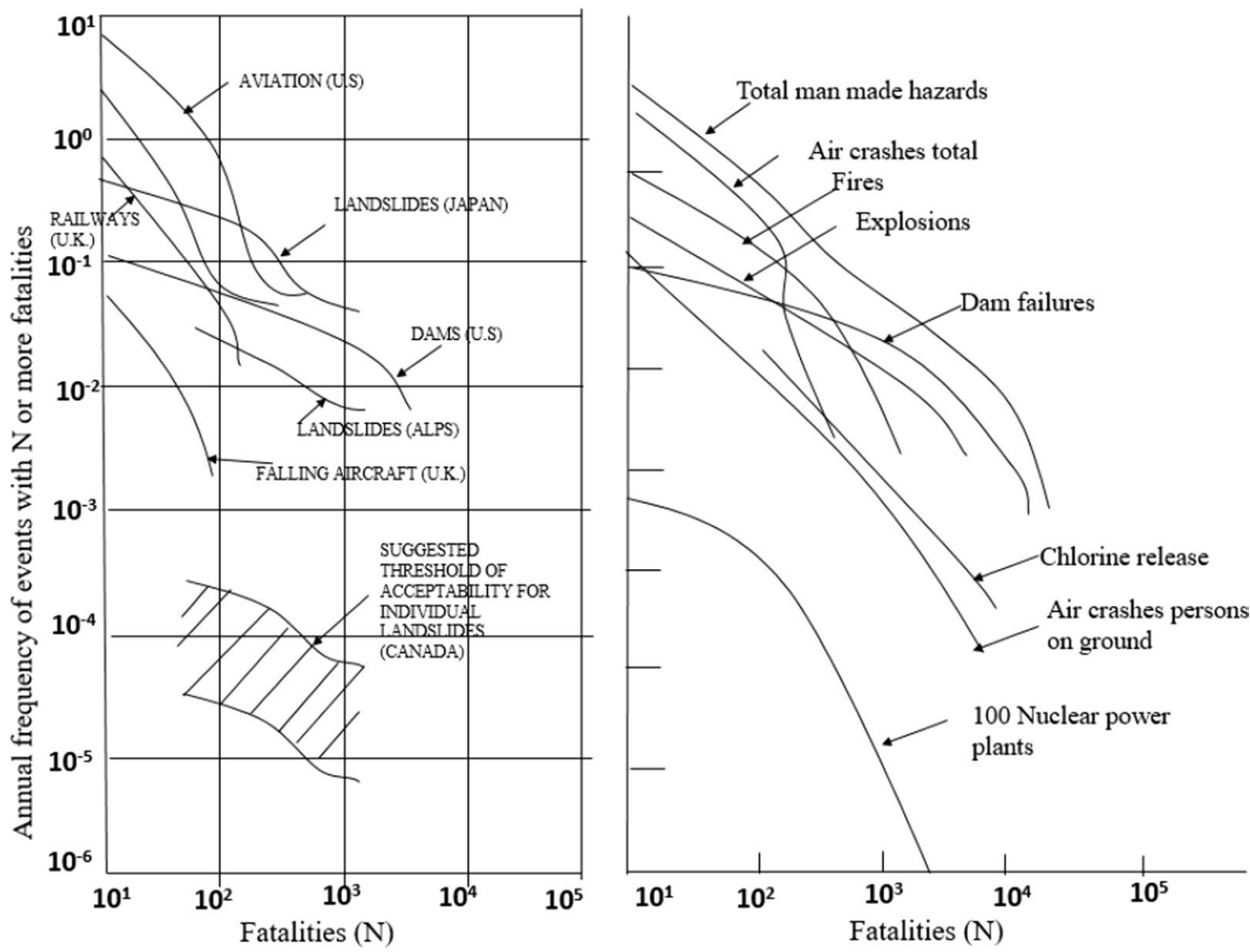

Fig. $3 \mathrm{~F}-\mathrm{N}$ curves demonstrating the number of fatalities against the annual frequency of occurrence for natural and man-made hazards (Modified from Van Westen et al. 2011)

shows the typical $F-N$-curves for various hazards. It can be seen that man-made hazards have a tendency to demonstrate a steeper curve than natural hazards (Van Westen et al. 2011).

\section{Landslide $F-N$ curves for various countries}

Figure 4 presents the family of $F-N$ curves for landslides compiled from various geographical locations. It should be clarified that some of the $F-N$ curves do not represent an entire country because of the unavailability of data. There are mixtures of $F-N$ curves extracted from different countries and local municipalities. It is apparent that the $F-N$ curve is unique to a country/location. From Fig. 4, the individual risk (1 death) for Guatemala is significantly lower than those of other nations. However, this highlights a bias in the Guatemala catalogue, which lacks comparable coverage. Another thing to note about Guatemala is that the $F-N$ curve only covers probabilities of single deaths and no more than that which reflects on the severe lack of data. It can be seen that the $F-N$ curve for China only begins for landslides that result in a minimum of 100 deaths while the Japanese $F-N$ curve only starts from 10 which signifies the incompleteness of the landslide catalogue of the former countries for low intensity scenarios (Guzzetti et al. 2002). As stated by Song et al. (2007), many organizations still do not possess sufficient database to progress very far in this direction with few exceptions such as Hong Kong. Nevertheless, the Japanese and Chinese $F-N$ curves stand higher than the curves computed for other countries, even for the shortest time intervals which denotes that the aforementioned nations faced a high landslide risk, with a great number of cataclysmic events that caused severe fatalities.

It can be seen that the $F-N$ curves of both Hong Kong and Canada share a very similar slope and trend and they converge at $N=20$. From there, the trend becomes different with Canada showing higher probabilities of casualties until they converge again at $N=70$. Interestingly, the maximum $N$ value of Hong Kong is lower than 100 even though it has a high population density living in steep hillsides. According to Duzgun and Lacasse (2005), the Hong Kong curve represents the performance of engineered slopes (risk imposed upon the community by designed slopes). At $N=10$, the city of Rio de Janeiro has almost the same $F$-value as China which is not surprising considering both Rio and China are heavily populated region and country, respectively. Canada, Nilgiri Hills, 


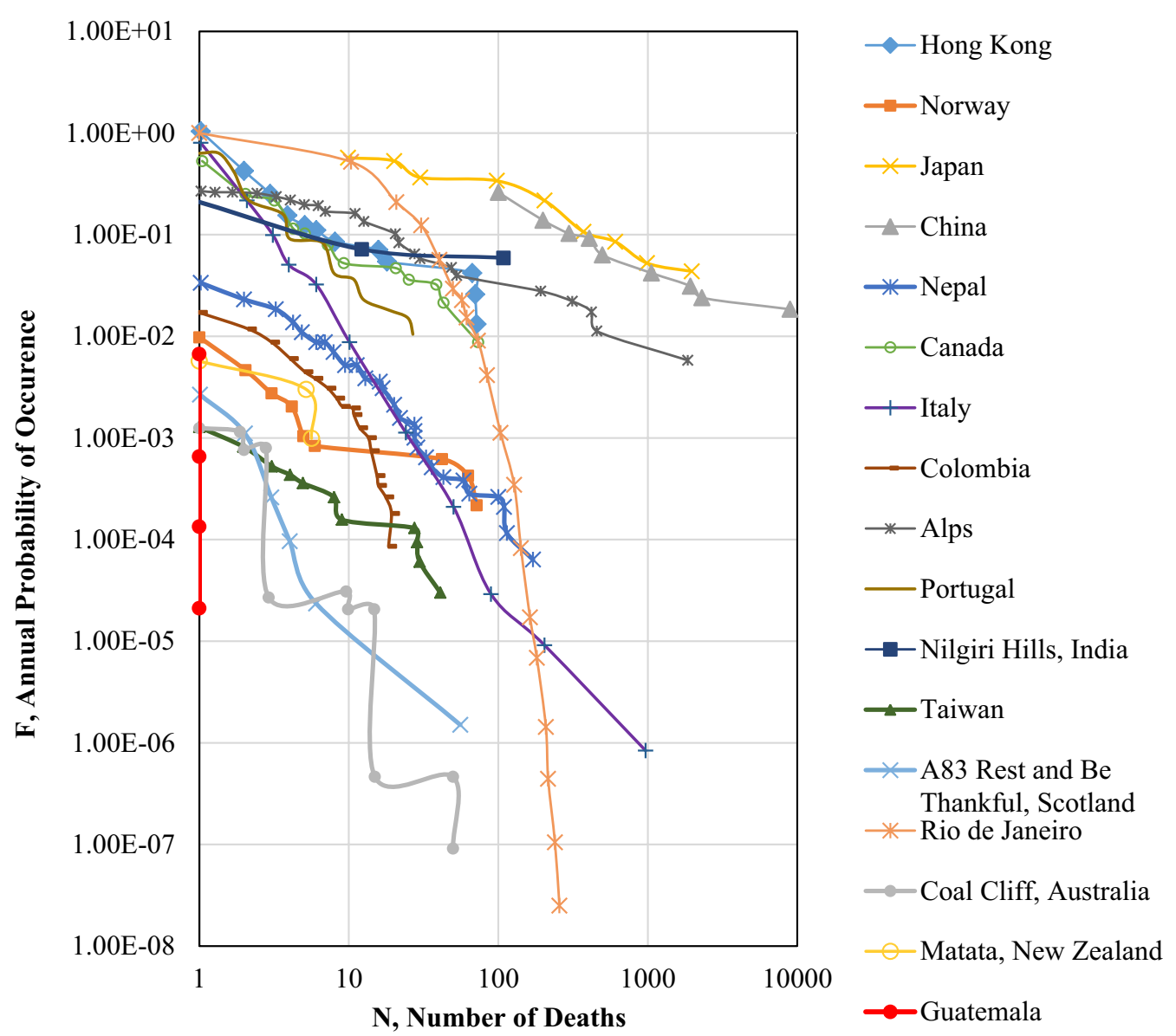

Fig. 4 Global comparison of frequency (F) versus number of deaths (N) curves (Guzzetti et al. 2002; Pacheco et al. 2002; Duzgun and Lacasse 2005; Hsi and Fell 2005; Jaiswal et al. 2011; Tsao et al. 2011; Whakatane District Council 2015; Pereira et al. 2017; Laporte 2018; Winter and Wong 2020)

India, and Hong Kong were observed to share approximately similar curves. The curves for Nepal and Rio de Janeiro both converged at $N=141$. However, for events associated with lower casualties (i.e. $N<100$ ), the probability of landslide fatality in Rio de Janeiro is significantly higher than that in Nepal. This is clearly related to the much higher population density in the city of Rio de Janeiro than Nepal as a country.

The population density as well as the hazard spatial distribution should be included to compare the $F-N$ curves of various nations (Duzgun and Lacasse 2005). Population density, $F$-values, and slope of the best-fit curve are tabulated in Table 2. The probability of occurrence, $F$ for a specific $N$ is governed by the slope of the curve. A steeper slope signifies a higher risk aversion or in other words, a lower probability of occurrence for a specific number of fatality or lower risk. For example, the slope of Japan's curve is -0.53 while Italy's curve has a slope of -1.99 . The probabilities of occurrence, $F$ for $N=100$ fatalities for Japan and Italy are 0.07 and 0.00005 , respectively which show that a higher risk level is associated with the slopes in Japan than in Italy. Comparisons of $F-N$ curves between developed and developing worlds and between different continents are shown in Fig. 5. It should be made clear that the curves of more discrete regions such as Nilgiri Hills, India and Matata, New Zealand were included in Fig. 5 as well. Overall, despite the curves being inconsistent, a general observation indicated that the $F-N$ curves of developing countries are mostly plotted higher than those of developed countries. In terms of continents, the Asian continent generally has a higher frequency of deaths followed by Latin America. This is because countries in Asia such as Japan are situated in a geographical location where natural disasters are frequent. Furthermore, countries like China and Nepal have many of their population living on hazardous slopes which have further increased the risk of landslide fatalities.

It was stated by Holcombe et al. (2016) that rapid unplanned development is causing a rise in 
Table 2 Population density (World Bank 2018), F-values, and slope of F-N curves for various geographical locations

\begin{tabular}{|c|c|c|c|c|c|}
\hline \multirow[t]{2}{*}{ Locations } & \multirow{2}{*}{$\begin{array}{l}\text { Population density/ } \\
\text { km² }^{2}\end{array}$} & \multirow[t]{2}{*}{ Slope of $F-N$ curve } & \multicolumn{3}{|l|}{ F-values } \\
\hline & & & $N=1$ & $N=10$ & $N=100$ \\
\hline Japan & 347 & -0.53 & - & 0.8 & 0.07 \\
\hline China & 148 & -0.61 & - & - & 0.06 \\
\hline Rio de Janeiro, Brazil & - & -3.3 & 1 & 0.52 & 0.0011 \\
\hline Italy & 203 & -1.99 & 0.9 & 0.008 & 0.00005 \\
\hline Portugal & 112 & -2.35 & 0.63 & 0.04 & - \\
\hline Hong Kong & 7096 & -0.79 & 0.6 & 0.01 & - \\
\hline Canada & 4 & -0.92 & 0.4 & 0.07 & - \\
\hline Alps & 215 & -0.538 & 0.29 & 0.16 & 0.003 \\
\hline Nilgiri Hills, India & - & -0.275 & 0.21 & 0.05 & 0.006 \\
\hline Nepal & 196 & -1.31 & 0.08 & 0.004 & - \\
\hline Colombia & 45 & -1.63 & 0.04 & 0.001 & - \\
\hline Norway & 15 & -0.72 & 0.006 & 0.001 & - \\
\hline Matata, New Zealand & 19 & -0.73 & 0.0057 & - & - \\
\hline $\begin{array}{l}\text { A83 Rest and be Thankful site, } \\
\text { Scotland }\end{array}$ & - & -1.924 & 0.002 & 0.00005 & - \\
\hline Taiwan & 637 & -0.89 & 0.00128 & 0.000157 & - \\
\hline Coal Cliff Australia & - & -2.375 & 0.00125 & 0.0000206 & - \\
\hline Guatemala & 153 & - & 0.000134 & - & - \\
\hline
\end{tabular}

(a) Developing world —Developed world

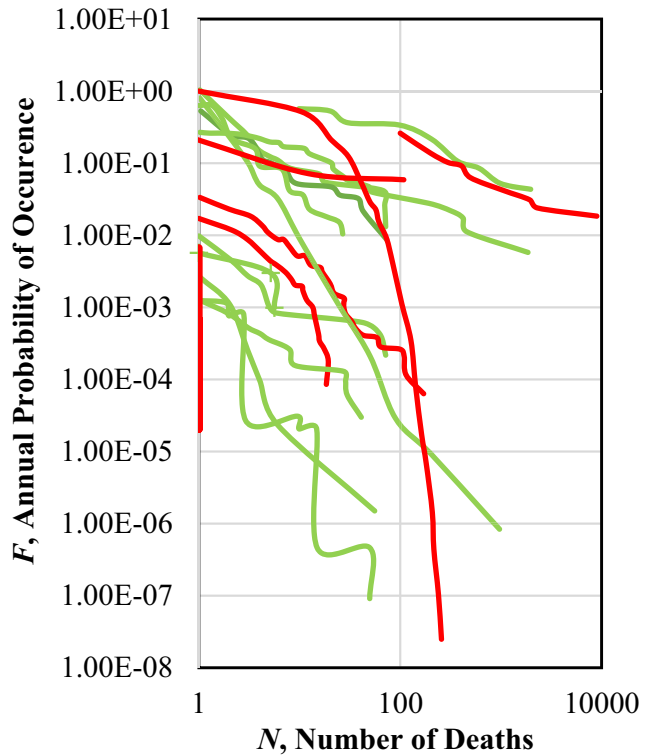

(b)
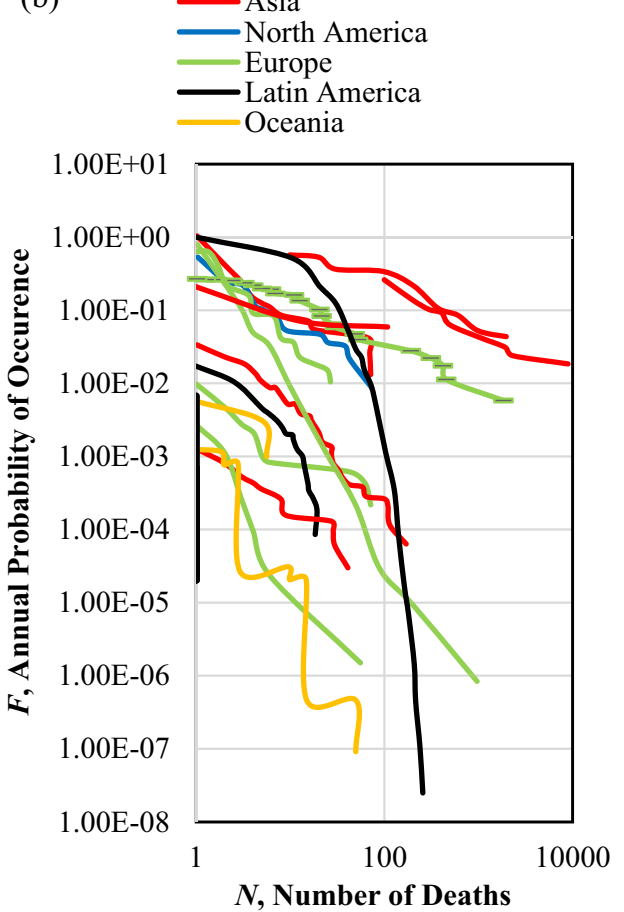

Fig. 5 F-N curves grouped based on a developed and developing worlds, b geographical continents

precipitation-triggered landslide risk in low-income areas in tropical developing nations. The number of people inhabiting overcrowded impoverished houses lacking infrastructure almost reaches the 1 billion mark exposing them to the dangers of both small and large scales catastrophes. In Latin America, Gross 
National Income (GNI) and value of life are generally low (Daniell et al. 2015; World Bank 2020) with many of their populations living in slums constructed on hazardous slopes with no compliance to safety standards. The majority of these slums are constructed on lands on which significant landslide hazards persist, i.e. unstable slopes (see Fig. 6) without any design or assessment for the factor of safety. This had further propagated the landslide hazard due to localised changes in drainage, vegetation, loadings, and topography, and hence increased the associated risk to the population. Disasters of these types serve as a warning sign of a bigger issue stemming from poverty as well as a poorly-organized development (Hungr et al. 2016). Unfortunately, there are no known $F-N$ curves available for countries in the African continent.

It is crucial to note that the $F-N$ curves only provide statistical readings and not the threshold of risk acceptance and tolerance. Nevertheless, the $F-N$ curves are useful for evaluating the current risk level of a region/country. This information is useful for developing the risk acceptance and tolerance levels for a country. As can be seen from Figs. 4 and 5, the landslide risk level varies considerably from a country to another, and hence different standards of acceptance and tolerance should be adopted with considerations of various factors (Duzgun and Lacasse 2005), which will be reviewed in further details in the following section.

\section{Concept of acceptable risk and tolerable risk}

It is crucial to differentiate between acceptable risks which the public aims to determine, mainly for new developments, and tolerable risks which they will live with, albeit lower risks still prevail as their main preference (AGS 2007). This applies to both property and loss of life. People in a society whose lives might be impacted by landslides, and authorities in charge of development approval must determine the acceptable and tolerable risks for property loss and damage (Song et al. 2007; Leventhal and Withycombe 2009). Practically, the authorities will be the ones obligated to ascertain the risk levels given its obligation to control hazards at the local municipal level. In most cases, that is the National or State authority or Local Government Area Council. Following are the brief definitions of acceptable risk and tolerable risk:

I. Acceptable Risk-A risk that the public is inclined to accept without regard to its management for life and work purposes. Further expenditure in lowering such risks is normally not taken under consideration by the public.

II. Tolerable Risk-A risk that the general public is inclined to live with in order to safeguard certain net benefits having faith that the particular risk is being properly contained. The risk level is periodically reviewed and lowered further whenever feasible. Also, the criteria where the ALARP principle, which stands for "As Low As Reasonably Practicable", may be applied so that the risk is mitigated to a marginally and practically tolerable level since the (a)

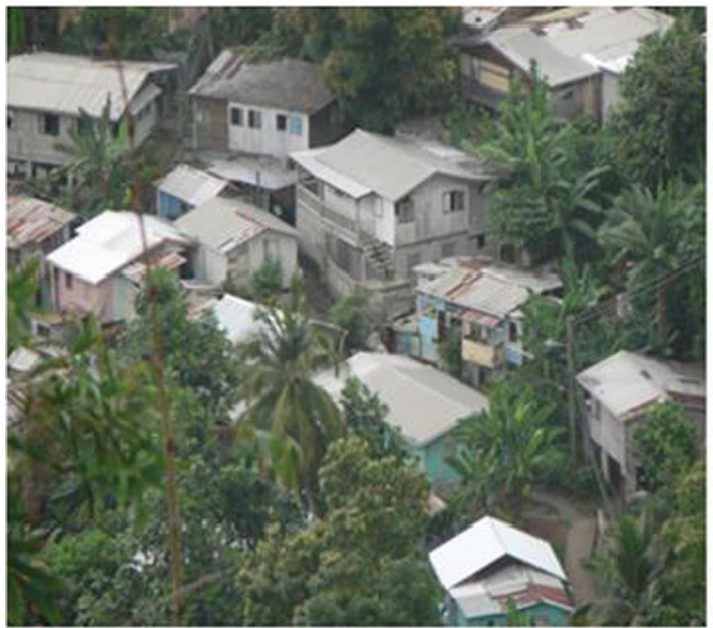

(b)

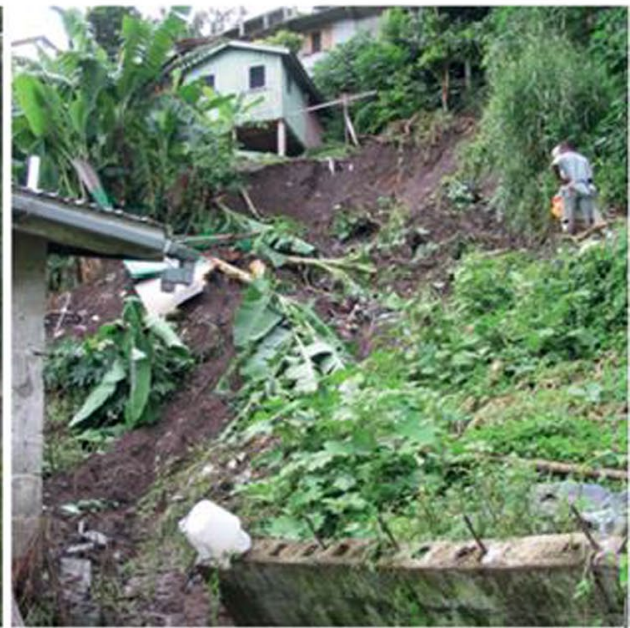

Fig. 6 a Archetypal unplanned housing on unstable slopes in Castries, Saint Lucia, Eastern Caribbean; b landslide on unplanned development (Holcombe et al. 2016) 


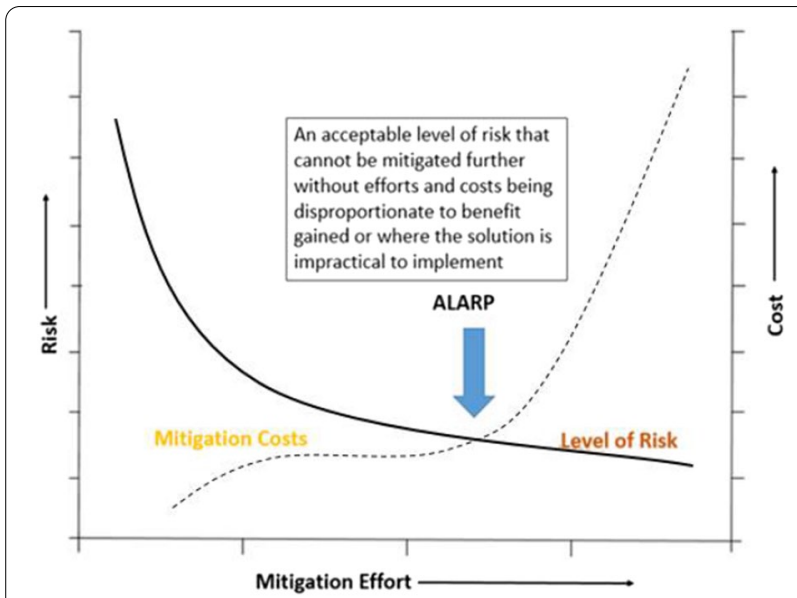

Fig. 7 Illustration of "As Low As Reasonably Practicable" ALARP principle for risk evaluation (Campbell et al. 2016)

reduction to further acceptable levels is not feasible with regards to the cost to the individual or public. Figure 7 shows the significance of ALARP (Campbell et al. 2016).

According to Winter and Bromhead (2012), society will be more tolerant towards landslides that occur for natural slopes than for engineered slopes, although the effects of climate change may cause recurring natural slope failures in a small area defeating this greater tolerance. Tolerable risks differ between nations subjected to historic exposure to landslides, control and ownership of slopes, and natural landslide hazards. Relevant regulators may choose to apply "acceptable risk" criteria for high-risk cases, i.e. hospitals, schools, as well as emergency services taking into account their significance, and also as a means of mitigating societal risk concerns. For involuntary individual risk, generally, the acceptable risk values will be in the frequency range of $10^{-5}$ to $10^{-6}$ per year while for voluntary risk, it will be typically between $10^{-3}$ to $10^{-4}$ per annum (Fell 1994).

Figure 8 shows a provisional risk criterion proposed for natural slopes in Hong Kong (Geotechnical Engineering Office 1999; Lacasse et al. 2010; Lacasse 2016). The degree of aversion is represented by the slope of the $F-N$ lines. Lines with a slope gradient of 1 are indicated as equi-risk, in which the points along the line have the same risk level. The $F-N$ curves may be conveyed by the equation:

$$
F \cdot N^{\alpha}=k(1)
$$

where $k$-value is $0.001, \alpha$ equals unity (2). The greater the $F-N$ slope, the higher the risk aversion (Anand 2015; Roy and Kshirsagar 2020). For example, for a slope of 2,

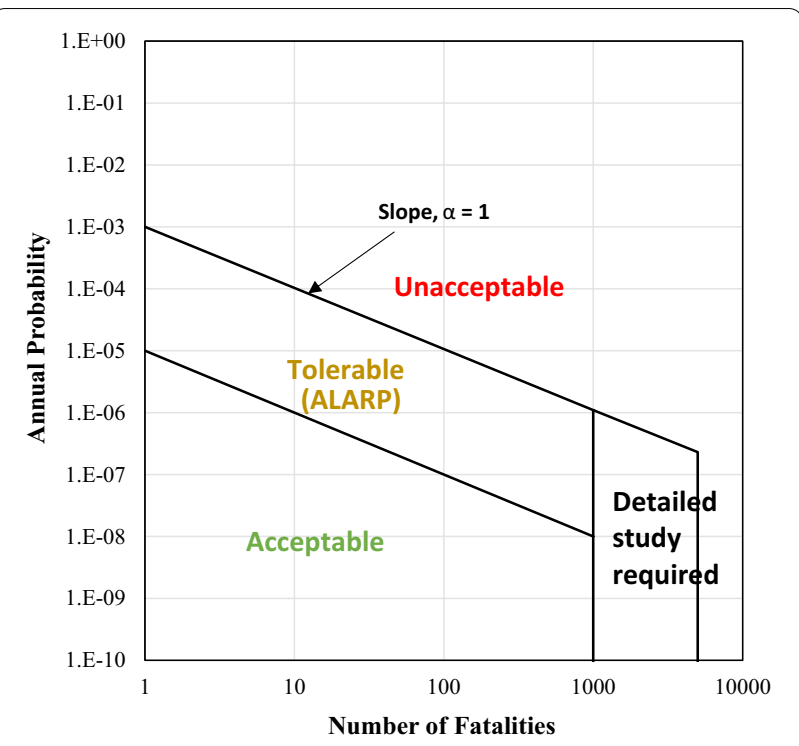

Fig. 8 Risk criterion proposed for natural slopes in Hong Kong. Modified from Geotechnical Engineering Office (1999), Lacasse et al. (2010), Lacasse (2016) and Strouth and McDougall (2020)

the risk criteria is such that the frequency of events that cause 100 deaths or greater must be 100 times lower than the frequency of events that cause 10 or more deaths (Roy and Kshirsagar 2020). The tolerable/ALARP region reflects the risk to be "As Low As Reasonably Practicable" which is illustrated in Fig. 8 (Campbell et al. 2016).

A study by Winter and Bromhead (2012) summarized issues that govern landslide risk acceptance such as planning and regulations, event footprint against vulnerability shadow, budgetary issue, vulnerability of vehicles all fit into the influences of social and economic factors on the risk acceptance. Figure 9 shows a conceptual ternary willingness diagram of various landslide incidents in different countries. The approaches of various nations in handling landslides are qualitatively compared to provide a better understanding of the factors involved in landslide risk mitigation.

It is clear that the risk level that exists in a particular area and the willingness to pay or financial power will, have a significant impact on the risk acceptance. Nevertheless, risk acceptance and financial power/willingness to pay are factors that are considered as forcing agents in the discourse on worldwide landslide risk mitigation. As stated by Turner (2018), industrialized nations have procedures for landslide mitigation planning and implementation that call for accurate knowledge of landslide hazards and risks. The landslide risk assessments are gradually becoming quantitative. Mitigation measures include structural and geotechnical procedures, in addition to political, legal, as well as administrative 


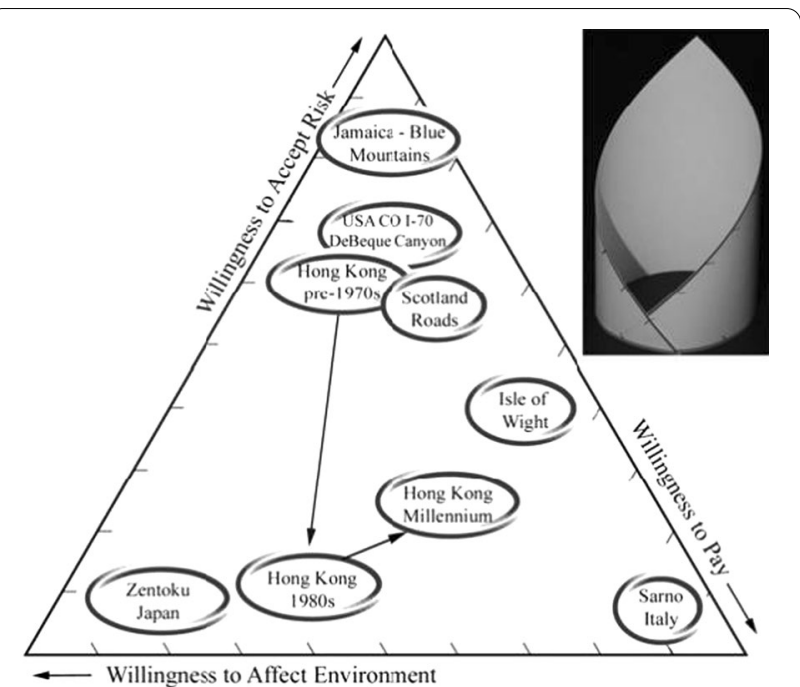

Fig. 9 Willingness diagram by Winter and Bromhead (2012) demonstrating various approaches to landslide risk in different countries

procedures that impact the lifestyle and behaviour of the endangered society. For example, Zentoku, Japan leans to the bottom left region of the Willingness diagram in Fig. 9 signifying a very high willingness to pay and alter the environment to mitigate landslide risk in the region. This implies that Japan has a tremendously low tolerance of landslide risk as well as the financial ability to pay to mitigate the risk.

In contrast, Jamaica's landslide mitigation approach in the Blue Mountains puts them at the top of the triangle, showing that there is a very high willingness to accept risk and a very low willingness to pay. Jamaica is a country with limited economic resources and that limited budget forces them to accept the risk (Winter and Bromhead 2012). Similar scenarios were reported by Yifru et al. (2015), where there was no mitigation carried out on the landslides that occurred along the road corridors of two Caribbean islands, i.e. Saint Lucia and Dominica (both known to be deprived islands). Focuses given to the two Caribbean islands were only for road repairs and debris removal. This observation further supported the willingness diagram of Winter and Bromhead (2012) which demonstrates that a limited economic resource leads to a low willingness to pay, and hence leads to a high acceptance of landslide risk. Most developing nations do not possess adequate resources, capacity, and technical skills to carry out landslide risk reduction measures to the required speed and level. Rather than lowering vulnerability, their central emphasis on handling landslides has been to respond actively to emergencies and catastrophes which again results in higher risk acceptance. Support and collaboration from developed nations are needed (Kjekstad and Highland 2009; Turner 2018).

From the foregoing, it can be concluded that if acceptable and tolerable societal risk levels are to be established, each country should select different levels governed by factors such as socioeconomic standing, Gross Domestic Product (GDP), statistical value of lives, as well as financial prowess of the country (Leroi et al. 2005; Roy and Kshirsagar 2020).

\section{A review of risk tolerance criteria for various countries Hong Kong}

In the late 90s, the Hong Kong Government provisional criterion for "potentially hazardous installations" for "landslides and boulder falls from natural terrain" was implemented by the Hong Kong Geotechnical Engineering Office (GEO) (Geotechnical Engineering Office 1999) (see Fig. 2). According to Wong (2005), the criterion was occasionally adopted in the country to determine landslide risk tolerance related to developments of structures and infrastructures, etc. in near proximity to modified or natural slopes. Hungr and Wong (2007) described that in order to scale the $F-N$ chart in proportion to its original reference frame (the perimeter of the industrial plant), it is used on a consultation area of around $500 \mathrm{~m}$ long section of a boundary between hazardous slopes and buildings.

The saga of the founding of the Hong Kong landslide risk management system was explained by Malone (2012). It was decided by the Hong Kong GEO that the methodology of the United Kingdom Health and Safety Executive (HSE) to create the risk tolerance criterion with a few adjustments could help in decision making procedures in Hong Kong in regards to landslides. The Hong Kong GEO conducted QRA on the basis of available records, which restricts the timeline to around 50 to 100 years. This also means that high magnitude infrequent landslides do not appear in the inventory and, the probabilities and levels of the infrequent landslides were then determined through extrapolation. This limited period over which landslide inventories exist, and the associated lack of data on high magnitude/low frequency landslides is a challenge with which all regions of the world must grapple.

Other than the $F-N$ diagram for societal risk, it is also recommended by GEO that individual risk tolerance criteria of 1 in 10,000 be applied for current residential areas and 1 in 100,000 for new developments. The ALARP method was employed quantitatively to Hong Kong scenarios to establish the feasibility of landslide remedial works, i.e. the Pat Heung landslide, North 
Lantau Expressway, Lei Yue Mun, and Shanti Heights, etc (Wong 2005).

\section{China}

Following a landslide that results in 79 casualties at Wulong, China on labour day of 2001, new legislation on landslide hazard and risk assessments were incited. However, no landslide individual and societal risk criteria have been recognized by the Chinese government (Song et al. 2007) though numerous criteria have been developed and employed for other projects such as dams. Nevertheless, the verdict on acceptable and tolerable risks lies in the decision of the client, owner, regulator, and persons at risk and not the risk analysts (Fell 1994).

The Chinese landslide societal risk criteria proposed by Song et al. (2007) is comparable to the Hong Kong acceptable and tolerable landslide risk criterion found in Fell (1994), Geotechnical Engineering Office (1999), and Dai et al. (2002). The proposed landslide risk criteria are about 3 times higher than the projected risk criterion for manmade structures such as buildings. More recently, landslide risk assessment has been implemented extensively in China, with real-life landslide case studies employed in various regions i.e. Western Hubei (Fu et al. 2020), eastern Jiangxi (Zhang et al. 2020), and Mayang county (Sui et al. 2020). It is further stated by Wu et al. (2020) that the Chinese government invented a system called 'Public Participation Monitoring and Warning' (PPMW) which aims to bring down mortality rate with the least cost by grouping residents to evacuate ahead of a disaster. It works by captivating the public in the disaster risk management operation.

\section{Australia}

In 1997, 18 deaths occurred as a result of the Thredbo landslide in Australia. This resulted in the development of a framework for risk-based landslide management by the Australian Geomechanics Society (AGS) (AGS 2007). It is stated in the framework that "risk evaluation is to be conducted by comparing estimated risks to levels of tolerable or acceptable risk, in order to assess priorities and options" and the risk tolerance criteria are to be determined by the "client/owner/regulator with advice from a technical specialist".

For individual risk, it is recommended by AGS (2000) that the tolerable individual risk criteria employed for Potentially Hazardous Industries, Australian National Committee on Large Dams (ANCOLD), as tabulated in Table 3, could be reasonably applied to engineered slopes as well (Lacasse 2016). Moreover, it is also being proposed that acceptable risks may be taken as one order of magnitude lower than tolerable risks.
Table 3 Proposed tolerable risks by AGS (2000) as seen in Lacasse (2016)

\begin{tabular}{ll}
\hline Slope types & Tolerable risk for loss of life \\
\hline Engineered slopes & $10^{-4} /$ year for person most at risk \\
& $10^{-5}$ year for average person at risk \\
New engineered slopes & $10^{-5}$ year for person most at risk \\
& $10^{-6} /$ year for average person at risk \\
\hline
\end{tabular}

It is then further stated by AGS (2007) that no risk tolerance criteria of Australia are legally binding lest the owner or regulator acknowledge it. Nevertheless, the landslide tolerance criteria developed in Hong Kong for Societal and Individual risk are endorsed in documented studies regarding landslide risk management practices in Australia (Fell et al. 2005).

\section{Canada}

A review by Evans et al. (2005) concluded that Canada has adequate comprehension of landslide hazards that it could deliver a regional quantitative risk assessment (QRA) as well as the design of tough risk-reduction procedures for majority areas that are heavily predisposed to landslides. North Vancouver was the first municipality in Canada to employ the Hong Kong individual risk acceptance criteria after the landslide in North Vancouver that occurred in 2005 due to heavy downpour which resulted in the destruction of two homes, one seriously injured resident, and one fatality (Hungr et al. 2016; Porter et al. 2017). Restrictions were enforced by the legislation on the development of residential areas, as well as redevelopment and rezoning in regions where the Personal Individual Risk (PIR) exceeds 1 to 10,000 for existing houses or 1 to 100,000 for new development. Extensive public engagement is of paramount importance in the legislative operation (District of North Vancouver 2009; Tappenden 2014).

During an extreme rainstorm between June 19 and 21 2013 that brought about flood, debris flow, and debris flood in Canmore, Alberta, numerous buildings and infrastructure suffered severe damage (Town of Canmore 2015). As a result, the municipality engaged consultants conducted thorough quantitative risk assessments (QRA) on debris flow and debris flood risk on the Cougar Creek fan, on which a part of Canmore is built. Return periods between 30 and 3000 years were adopted for the hazard circumstances (Hungr et al. 2016). The main focus of the QRA was on direct building damage, grievances, and casualties by utilizing the Hong Kong risk tolerance criterion. A total of 190 areas in Canmore were found to have unacceptable individual and societal risks. It was not feasible to relocate the public residing there, hence four 
proposed options for mitigation were studied extensively, resulting in the construction of a debris flood containment structure (approximately height $30 \mathrm{~m}$ and width $100 \mathrm{~m}$ storage capacity $650,000 \mathrm{~m}^{3}$ ) to reduce the unacceptable risk as much as possible to the ALARP/tolerable zone (Town of Canmore 2015). Problems regarding practicability, impartiality as well as affordability were taken into account. Since then, QRA has also been conducted by other local and provincial government regulators in British Columbia and Alberta (Porter et al. 2017), which is a crucial move to obtain supports of stakeholders.

Since 2005, following a certain amount of public consultation, it is widely recognized that Canadian's insights and values in regards to landslide risk are similar to those of Hong Kong (Strouth and McDougall 2020). While there is no universal acceptance, $F-N$ curves have influenced land-use decision making processes exceeding 50 landslides and steep-creek flood hazard regions. Since 2020, the tolerable and acceptable risk criteria have been heavily referenced with discussions of integrating them into municipal and provincial guidelines, regulations, as well as design codes (Strouth and McDougall 2020).

\section{New Zealand}

In New Zealand, local governments were delegated with risk tolerance criteria by the New Zealand Resource Management Act. According to Enright (2015), the Hong Kong risk tolerance criteria were employed by the City of Christchurch following the 2010 and 2011 earthquakes. GNS science proposed a tolerable risk threshold for natural hazards of 1 in $10,000\left(10^{-4}\right)$ which was deemed to be too high and not acceptable as it doubles the number of "annual" casualties of the 2011 Christchurch earthquake. The study proposed that the annual tolerable risks threshold for existing risks to be $10^{-5}$ and $10^{-6}$ for new risks. However, the application of these criteria is still undergoing tests in the local courts and there is a possibility that they will be used by other local authorities. As of present, there are no restrictions placed on land use development for debris flow deposits adjoining the borders of active volcanoes which could only be a century old.

\section{Norway}

Throughout history, the Norwegian Fjords have been impacted by large rock slope failures triggering tsunamis that cause many deaths (Hermanns et al. 2013). A trio of the most epic of natural disasters transpired in the twentieth century where tsunamis caused by massive rockslides into fjords or lakes (Loen in 1905 and 1936 and Tafjord in 1934), claiming an excess of 170 lives (Eidsvig et al. 2011). Over the past few years, the Geological Survey of Norway has employed a systematic mapping method to distinguish unstable rock slopes disposed to calamitous failures, so that future events could be predicted and the population at risk could become accustomed to the hazard. The vulnerable regions are continuously monitored and an early warning system together with an evacuation plan is at hand (Hermanns et al. 2013). In 2015, procedures were established by the Direktoratet for Byggequalitet to specify development restrictions in regions vulnerable to landslides or landslide-generated waves (Clague et al. 2015). The restrictions take into account single and multi-family structures of fewer than 10 households, and construction is only allowed if the probability of landslide impact falls below the 1000-year return period event. Facilities and tall buildings housing numerous occupants i.e. schools, hospitals must be situated in zones with a probability of land sliding impact under the 5000-year return period event. There are exceptions such as when "the consequences of building restrictions are serious, and the construction has a significant impact on the society." In addition, exceptions are also allowed for scenarios where a warning could be given out three days prior to the incident. As of the present, 523 unstable rock slopes were detected, of which 110 were categorized as hazardous and risky. Out of the 110 hazardous and risky slopes, hazard zones were found in 48 slopes resulting in impediments on building projects. 7 sites were labelled as high risk and they are under constant monitoring (Hermanns et al. 2020).

\section{Switzerland}

Bründl et al. (2009) briefly explained that the Swiss National Platform for Natural Hazards (PLANAT) recommended an individual landslide risk "goal" of 1 in 100,000 per year for residential areas in the year 2005. However, the government of Switzerland apparently has not approved the usage of risk tolerance criteria for natural disasters. The present practice in avalanche warning demonstrates that educational courses are one of the crucial components in introducing new ways and skills to natural hazard experts. It is one of the means of communicating risk and there is a high possibility that educational courses will serve as the main part of integral risk management in Switzerland (Bründl et al. 2009). Furthermore, frequent training and educational courses will result in an increased public awareness towards potential consequences, as well as improvement to the compliance rate of the warning systems. Although showing promising results during the Preonzo rockfall event (zero injury and everybody evacuated successfully), further studies are still required to evaluate the effectiveness of the system on the basis of an integrated risk management approach (Sättele et al. 2016a, b, c). 
It was stated by the Swiss Ministry of the Environment that "while industrial risks can be governed by legislations using risk tolerance criteria, the same does not apply to natural hazard risks". This is an arguable statement that refuted by Hungr et al. (2016). The risk tolerance criteria have been well applied to natural hazards in different parts of the world such as Hong Kong (Wong 2005; Wong and Ko 2005; Chiu 2015), the UK (Winter and Wong 2020), the Netherlands (Hungr et al. 2016), Australia (Leventhal and Withycombe 2009), Italy (Rossi et al. 2019) and Canada (Town of Canmore 2015; Strouth and McDougall 2020).

A documented discourse by PLANAT (National Platform for Natural Hazards) (2014) regarding tolerable landslide risk criteria stated that "The average risk of death for human beings is not significantly augmented by natural hazards. The yearly risk of death resulting from natural hazards is significantly lower than the average probability of death for the age group with the lowest mortality rate in Switzerland." It can be concluded that their local regulators would prefer to use the landslide hazard probability assessments described in Lateltin et al. (2005). According to Lateltin et al. (2005), it was made mandatory by the new Federal Ordinances on Flood and Forest Protection for the cantons to develop hazard maps for incorporation into the regional and local development plans. This program was subsidized by the federal authorities up to $70 \%$. The three steps of constructing the hazard maps were outlined by Raetzo et al. (2002) as follows:

(i) Hazard identification step which comprises making an inventory of past slope failures.

(ii) Hazard assessment of the magnitude or intensity of landslides with time. Hazards are mapped into one of four hazard classes based on the probability of the land sliding hazard: high danger (probability: 82-100\%; red zone), moderate danger (probability: 40-82\%; blue zone), low danger (probability: 15-40\%; yellow zone) and no danger (probability: $<15 \%$; white zone);

(iii) Risk management and land-use planning

It was made mandatory by the federal government that the maps must follow a standard colour coding: red where construction is prohibited, blue where construction is permitted provided certain safety requirements are fulfilled, and yellow where construction can be carried out without any restriction. Hazard maps are deemed invaluable for planning protective measures such as warning systems and emergency plans (Raetzo et al. 2002; Lateltin et al. 2005).

\section{Malaysia}

Based on data obtained from the Global Landslide Catalog (GLC) of the United States National Aeronautical Space Administration (NASA), Malaysia is the 10th highest ranked country for the highest number of slope failures, with 171 major slope failures between 2007 and March 2016 (Abd Majid and Rainis 2019). The majority of the landslides occurred on cut slopes or embankments alongside roads and highways in mountainous regions with a few occurring close to high-rise apartments and residential areas, resulting in numerous causalities.

Over the years, there have been numerous studies conducted on Malaysian landslide hazards using various methods such as GIS (Mukhlisin et al. 2010; Althuwaynee and Pradhan 2017; Abd Majid and Rainis 2019), statistical logistic regression method (Lee and Pradhan 2007; Pradhan and Lee 2010) and deterministic safety factor method (Ng 2012; Ismail and Yaacob 2018). However, research on acceptable and tolerable risk is still scarce in Malaysia, with a few researchers (Ahmad et al. 2017; Roslee 2019) having a more thorough understanding of it. It was proposed by Ahmad et al. (2017) that the interim risk criteria for Malaysia should be higher (higher acceptance of risk, one fatal landslide in every 50 years) than Hong Kong (one fatal landslide every 1000 years) while Roslee (2019) proposed a risk tolerance criterion similar to that found in Hong Kong (Song et al. 2007; Lacasse et al. 2010). It can be concluded that QRA and landslide risk assessments are still a developing art in Malaysia and much surveys and studies are still required.

\section{Comparison of risk tolerance criteria}

Figure 10 presents comparisons between societal risk criteria adopted by different countries. While there are variations, the risk levels of Denmark, New South Wales, China, and ANCOLD/AGS generally converge at the anchor point of $F=1 \times 10^{-4} /$ year ( 1 in 10,000$)$ for $N=10$ casualties. Most countries adopt $F$ between $1 \times 10^{-2} /$ year to $1 \times 10^{-3} /$ year for $N=1$ of individual risk. The Netherlands, the Czech Republic, and European Commission (EC) have the most risk-averse slope; the steepest compared to those of other nations and entities. The risk criterion of Malaysia proposed by Ahmad et al. (2017) is liberal and has the highest risk tolerance $(\mathrm{N}=1000$ occurring at a frequency of $1 \times 10^{-4} /$ year). The Chinese risk criterion proposed by Song et al. (2007) is exactly the same as the one of the Australian National Committee on Large Dams (ANCOLD)/Australian Geomechanics Society (AGS). It can be seen that the French criterion is not governed by the number of fatalities, $N$. This will lead to a lower level of safety at high $N$ values and at the same time result in extremely stringent and uneconomical safety 


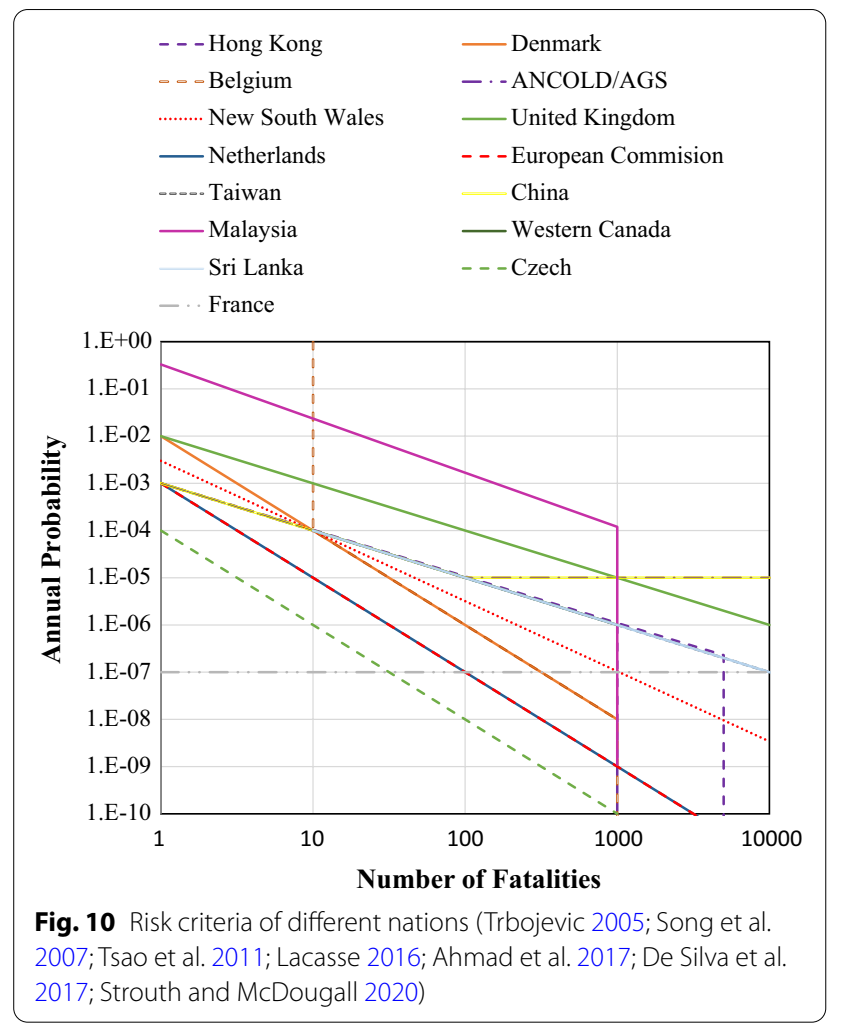

procedures at low $N$ values. Remarkably, lowland nations such as Belgium and the Netherlands employ stricter, more risk-averse criteria than mountainous nations such as Hong Kong and the UK as seen in the steeper slope and a lower $F$ value for $N=1$. As events and fatalities are rare in any case in lowland nations, it is relatively straightforward to establish and work successfully with stricter risk-averse criteria.

As seen in Fig. 10, the risk tolerance criteria for most countries fall below the Hong Kong criteria with the exception of Malaysia and the UK. The risk criteria of Denmark and New South Wales (NSW) are higher than Hong Kong's at lower fatalities until they converge at $\mathrm{N}=10$. At higher $N$ levels, the $F$ s of NSW and Denmark fall below Hong Kong's as evident in its steeper slope, which signifies a more stringent risk aversion and lower tolerance of risk for higher fatalities $(\mathrm{N}>10)$. The risk criteria of many countries lie below Hong Kong's suggesting a more stringent approach should be employed when it comes to risk assessments. However, the Hong Kong criterion is still widely adopted and referred to in other societies (Fell et al. 2005; Strouth and McDougall 2020).

The criterion proposed by Malaysia, a developing country, is above the criteria of other nations. It has the highest risk tolerance compared to other countries which is unduly liberal and calls for improvements to be made. Other developing countries such as China and Sri Lanka employ risk criteria similar to that of developed countries (China's being exact same criterion as that of Australia's, while Sri Lanka uses the same slope and $F=1 \times 10^{-3}$ for $N=1$ as that of Hong Kong's). It can be assumed that risk assessment is still new in many developing countries. Many of them employ the criteria of developed countries rather than making their own. As stated by Duzgun and Lacasse (2005), every nation should develop its own risk criterion as they all possess different $F-N$ curves. More works should be devoted to developing risk tolerance criteria particularly for less developed and mountainous countries.

\section{Conclusion}

It is apparent that every nation has its own priorities and approaches towards landslide risk management. While it is interesting to compare the broad range of policies and discussions among various nations worldwide, this review by far does not feature coverage on the countries of the African continent. There is practically no or very limited data available on the QRA of landslides in the African continent. It is also clear from the comparison of $F-N$ curves that the Asian world has the highest frequency of landslide deaths followed by Latin America.

Generally, the developed countries impose stringent risk "acceptance" criteria for death, ranging from 1 in 10,000 to 1 in 100,000 annual individual risks of loss of life. Although it is easy to state that the landslide risk criterion should have a minimum level of tolerance for landslides, i.e. $F=1 \times 10^{-3}$ for $N=1$, the acceptance of tolerance for landslides in every country will be governed by its financial standing. While a developing nation might face similar matters in risk governance and decision-making as the developed nations, the tradeoff between economy and safety might differ (Roy and Kshirsagar 2020). Developments that occur in developing nations will amass bigger benefits than their developed counterpart. For example, the construction of railways, roads may contribute to job opportunities, easier access to certain areas, and goods transportation which will help to increase turnover and create wealth to boost the economy (European Maritime Safety Agency 2015). However, against these potential advantages, the development of roads may inflict higher risk to the users i.e. landslides that occur along roads in Scotland, Jamaica, and Colorado as well as many others mentioned by Winter and Bromhead (2012). Nevertheless, under an agreed level of risk, there are potentially higher net benefits from the developments of a developing nation than for a developed one. Thus, should a variety of risk acceptance and tolerance criteria be employed in the developing nations in regards to their developed counterparts? An unduly liberal risk acceptance criteria will bring about 
more development but at the expense of higher societal risk. On the contrary, an extremely conservative acceptance criterion will hamper development and economics. Under these circumstances, cost-benefit considerations will be required to formulate a suitable acceptance criterion. Technically, risk acceptance criteria need to be established in a way that the cost spent must not be in gross disproportion to the potential benefits-"the risk being insignificant in relation to the sacrifice", as quoted from Lee and Jones (2014). Regardless, the rationalization of acceptance of hazardous developments in developing nations at a risk level which is deemed unacceptable in the developed nations remains a challenge. Criterion should be developed locally with historical landslide inventory, public perception, and engineering aspects being considered.

From the present review, it was found that many countries already have their landslide risk tolerance criteria in place (some were self-developed while others were adapted from the models of developed countries). However, the actual enforcement and implementation of the criteria in real life landslide risk control are still not encouraging, particularly for less developed countries. As a way forward, cooperation and support from agencies of developed countries such as the United States Agency for International Development (USAID), the UK's Department for International Development (DFID), the Australian Agency for International Development (AusAID), the Canadian International Development Agency (CIDA), and the Japan International Cooperation Agency (JICA) will be highly desirable in providing their technical and financial aids to mitigate landslide hazards in the least developed countries.

\section{Acknowledgements}

This study is funded by the Fundamental Research Grant Scheme (FRGS), Ministry of Higher Education (MOHE) Malaysia, Ref No.: FRGS/1/2019/TK01/ UNIM/02/2.

\section{Authors' contributions}

KBS: literature search, review, analysis, writing. MLL: idea, editing, funding. SYW: idea, editing, formatting. All authors read and approved the fnal manuscript.

\section{Availability of data and materials}

All data generated or analysed during this study are included in this published article.

\section{Declarations}

Ethical approval

No ethical approval is required for this review article.

\section{Competing interests}

The authors declare no competing interests.

Received: 8 November 2021 Accepted: 15 January 2022 Published online: 25 January 2022

\section{References}

Abd Majid N, Rainis R (2019) Aplikasi Sistem Maklumat Geografi (GIS) dan Analisis Diskriminan dalam Pemodelan Kejadian Kegagalan Cerun di Pulau Pinang, Malaysia. Sains Malays 48:1367-1381. https://doi.org/10. 17576/jsm-2019-4807-06

AGS (2000) Landslide risk management concepts and guidelines. Aust Geomech J 35:49-92

AGS (2007) Guidelines for landslide risk management. J News Aust Geomech Soc 42

Ahmad AR, Amin ZA, Abdullah CH (2017) Public awareness and education programme for landslide management and evaluation using a social research approach to determining "acceptable risk" and "tolerable risk" in landslide risk areas in IPL-194, IPL-207). In: Advancing culture of living with landslides, pp 437-447. https://doi.org/10.1007/ 978-3-319-59469-9

Althuwaynee OF, Pradhan B (2017) Semi-quantitative landslide risk assessment using GIS-based exposure analysis in Kuala Lumpur City. Geom Nat Hazards Risk 8:706-732. https://doi.org/10.1080/19475705.2016.12556 70

Anand N (2015) Risk criteria and its acceptance in Indian context. Res J Chem Environ Sci 3:36-43

Aristizábal E, Sánchez O (2020) Spatial and temporal patterns and the socioeconomic impacts of landslides in the tropical and mountainous Colombian Andes. Disasters 44:596-618. https://doi.org/10.1111/disa. 12391

Batista EF, Passini LDB, Kormann ACM (2019) Methodologies of economic measurement and vulnerability assessment for application in landslide risk analysis in a highway domain strip: a case study in the Serra Pelada Region (Brazil). Sustainability 11(21):6130. https://doi.org/10.3390/ su11216130

Bobrowsky P, Couture R (2014) Landslide terminology, Canadian technical guidelines and best practices related to landslides: a national initiative for loss reduction. In: Sassa K, Rouhban B, Briceño S, McSaveney M, He B (eds) Landslides: global risk preparedness. Springer, Berlin. https://doi. org/10.4095/293940

Bründl M, Romang HE, Bischof N, Rheinberger CM (2009) The risk concept and its application in natural hazard risk management in Switzerland. Nat Hazards Earth Syst Sci 9:801-813. https://doi.org/10.5194/ nhess-9-801-2009

Campbell C, Conger S, Gould B et al (2016) Technical aspects of Snow Avalanche Risk Management-resources and guidelines for avalanche practitioners in Canada. Canadian Avalanche Association, Revelstoke

Chiu JKY (2015) Landslide risk management perceptions in territories—comparative case studies of Hong Kong and Norway. MSc thesis, University of Oslo, Oslo

Clague J, Hungr O, Morgenstern NR, VanDine D (2015) Cheekye River (Ch'kay Stakw) and Fan landslide risk tolerance criteria. Report prepared for the Province of British Columbia, Squamish Nation and its Partnership, and District of Squamish.

Cruden DM, Thomson S, Bomhold BD et al (1989) Landslides: extent and economic significance in Canada. In: Brabb EE, Harrod BL (eds) Lanslides: extent and economic significance. Rotterdam, Balkema, pp 1-24

Dai FC, Lee CF, Ngai YY (2002) Landslide risk assessment and management: an overview. Eng Geol 64:65-87. https://doi.org/10.1016/S0013-7952(01) 00093-X

Daniell JE, Schaefer AM, Wenzel F, Kunz-Plapp T (2015) The value of life in earthquakes and other natural disasters: historical costs and the benefits of investing in life safety. In: Proceedings of tenth pacific conference on earthquake engineering. Building an earthquake-resilient pacific, pp 6-8

De Silva KGVK, Gunasekera MY, De Alwis AAP (2017) Derivation of a societal risk acceptance criterion for major accident hazard installations in Sri Lanka. Process Saf Environ Prot 111:388-398. https://doi.org/10.1016/j. psep.2017.07.025

Dilley M, Chen RS, Deichmann U et al (2005) Natural disaster hotspots: a global risk analysis. World Bank Publications, Washington, DC

District of North Vancouver (2009) Report to council: natural hazards risk tolerance criteria. District of North Vancouver

Dowling CA, Santi PM (2014) Debris flows and their toll on human life: a global analysis of debris-flow fatalities from 1950 to 2011. Nat Hazards 71:203-227. https://doi.org/10.1007/s11069-013-0907-4 
Duzgun S, Lacasse S (2005) Vulnerability and acceptable risk in integrated risk assessment framework. In: Hungr O, Fell R, Couture R, Eberhardt E (eds) Landslide risk management. CRC Press, Boca Raton, pp 515-526. https://doi.org/10.1201/9781439833711-35

Eidsvig UM, Medina-Cetina Z, Kveldsvik V et al (2011) Risk assessment of a tsunamigenic rockslide at Åknes. Nat Hazards 56:529-545. https://doi. org/10.1007/s11069-009-9460-6

Enright PA (2015) Is there a tolerable level of risk from natural hazards in New Zealand? Georisk 9:1-8. https://doi.org/10.1080/17499518.2014.10003 41

European Commission (2021) Global overview of landslides with fatalities (1 August-31 December 2020). In: ERCC—Emergency Response Coordination Centre. https://erccportal.jrc.ec.europa.eu/Maps/Daily-maps\#/ maps/3645. Accessed 10 June 2021

European Maritime Safety Agency (2015) Risk acceptance criteria and risk based damage stability, final report, part 2: formal safety assessment. European Maritime Safety Agency, Lisbon

Evans SG, Cruden DM, Bobrowsky PT (2005) Landslide risk assessment in Canada; a review of recent developments. In: Hungr O, Fell R, Couture R, Eberhardt E (eds) Landslide risk management. CRC Press, Boca Raton, pp 361-374. https://doi.org/10.1201/9781439833711-16

Fell R (1994) Landslide risk assessment and acceptable risk. Can Geotech J 31:261-272. https://doi.org/10.1139/t94-031

Fell R, Ho KKS, Lacasse S, Leroi E (2005) State of the Art Paper 1 A framework for landslide risk assessment and management. In: International conference on landslide risk management, Vancouver, vol 31

Froude MJ, Petley DN (2018) Global fatal landslide occurrence from 2004 to 2016. Nat Hazards Earth Syst Sci 18:2161-2181. https://doi.org/10.5194/ nhess-18-2161-2018

Fu S, Chen L, Woldai T et al (2020) Landslide hazard probability and risk assessment at the community level: a case of western Hubei, China. Nat Hazards Earth Syst Sci 20:581-601. https://doi.org/10.5194/ nhess-20-581-2020

Geotechnical Engineering Office (1999) Landslides and Boulder falls from natural terrain: interim risk guidelines. GEO Report No. 75. Homantin, Kowloon, Hong Kong

Görüm T, Fidan S (2021) Spatiotemporal variations of fatal landslides in Turkey. Landslides 18:1691-1705. https://doi.org/10.1007/s10346-020-01580-7

Guzzetti F, Cipolla F, Lolli O et al (2002) Information system on historical landslides and floods in Italy. In: Urban hazards forum. John Jay College, CUNY, New York.

Haque U, Blum P, da Silva PF et al (2016) Fatal landslides in Europe. Landslides 13:1545-1554. https://doi.org/10.1007/s10346-016-0689-3

Hermanns RL, Blikra LH, Anda E et al (2013) Systematic mapping of large unstable rock slopes in Norway Reginald. Landslide Sci Pract 1:29-34. https://doi.org/10.1007/978-3-642-31325-7

Hermanns RL, Oppikofer T, Böhme M et al (2020) Mapping the hazard and potential consequences for unstable rock slopes in Norway. In: AGU Fall meeting abstracts, p NH034-09

Holcombe EA, Beesley MEW, Vardanega PJ, Sorbie R (2016) Urbanisation and landslides: hazard drivers and better practices. Proc Inst Civ Eng Civ Eng 169:137-144. https://doi.org/10.1680/jcien.15.00044

Hsi JP, Fell R (2005) Landslide risk assessment of coal refuse emplacement. In: Hungr O, Fell R, Couture R, Eberhardt E (eds) Landslide risk management. CRC Press, Boca Raton, pp 535-542. https://doi.org/10.1201/ 9781439833711-37

Hungr O (2016) A review of landslide hazard and risk assessment methodology. Landslides Eng Slopes Exp Theory Pract 1:3-27. https://doi.org/10. 1201/b21520-3

Hungr O, Wong HN (2007) Landslide risk acceptability criteria: are F-N plots objective? Geotech News 25:47-50

Hungr O, Clague J, Morgenstern NR et al (2016) A review of landslide risk acceptability practices in various countries. Landslides Eng Slopes Exp Theory Pract 2:1121-1128. https://doi.org/10.1201/b21520-135

Ismail NI, Yaacob WZW (2018) An investigation of landslides in Bukit Aman and Puncak Setiawangsa, Kuala Lumpur, Malaysia. AIP Conf Proc 1940:20031. https://doi.org/10.1063/1.5027946

Jaiswal P, Van Westen CJ, Jetten V (2011) Quantitative estimation of landslide risk from rapid debris slides on natural slopes in the Nilgiri Hills, India. Nat Hazards Earth Syst Sci 11:1723-1743. https://doi.org/10.5194/ nhess-11-1723-2011
Jones FO (1974) Landslides of Rio de Janeiro and the Serra das Araras escarpment, Brazil. Int J Rock Mech Min Sci Geomech Abstr 11:A46. https:// doi.org/10.1016/0148-9062(74)92862-9

Kirschbaum D, Stanley T, Zhou Y (2015) Spatial and temporal analysis of a global landslide catalog. Geomorphology 249:4-15. https://doi.org/10. 1016/j.geomorph.2015.03.016

Kjekstad O, Highland L (2009) Economic and social impacts of landslides. In: Sassa K, Canuti P (eds) Landslides_-disaster risk reduction. Springer, Berlin, pp 573-587. https://doi.org/10.1007/978-3-540-69970-5_30

Klose M, Damm B, Terhorst B (2015) Landslide cost modeling for transportation infrastructures: a methodological approach. Landslides 12:321-334. https://doi.org/10.1007/s10346-014-0481-1

Klose M, Maurischat P, Damm B (2016) Landslide impacts in Germany: a historical and socioeconomic perspective. Landslides 13:183-199. https://doi. org/10.1007/s10346-015-0643-9

Lacasse S (2016) Hazard, reliability and risk assessment—research and practice for increased safety. In: Proceedings of the 17th Nordic geotechnical meeting, Reykjavik, pp 17-42

Lacasse S, Nadim F (2014) Landslide risk assessment and mitigation strategy. In: Duan L (ed) Bridge engineering handbook-superestructure desing, 2nd edn. CRC Press, Boca Raton, pp 31-61. https://doi.org/10.1201/ b15621

Lacasse S, Nadim F, Kalsnes B (2010) Living with landslide risk. Geotech Eng J SEAGS AGSSEA 41:1-13

LaPorte D (2018) Evaluating landslide risk management in Guatemala City through a study of risk perception and behavior changes. Colorado School of Mines, Golden

Lateltin O, Haemmig C, Raetzo H, Bonnard C (2005) Landslide risk management in Switzerland. Landslides 2:313-320. https://doi.org/10.1007/ s10346-005-0018-8

Lee EM, Jones DKC (2014) Landslide risk assessment, 2nd edn. ICE Publishing, London

Lee S, Pradhan B (2007) Landslide hazard mapping at Selangor, Malaysia using frequency ratio and logistic regression models. Landslides 4:33-41. https://doi.org/10.1007/s10346-006-0047-y

Leroi E, Bonnard C, Fell R, McInnes R (2005) Risk assessment and management. In: Hungr O, Fell R, Couture R, Eberhardt E (eds) Landslide risk management. CRC Press, Vancouver, pp 159-198

Leventhal A, Withycombe G (2009) Landslide risk management for Australia. Aust J Emerg Manag 24:42-52

Lin Q, Wang Y (2018) Spatial and temporal analysis of a fatal landslide inventory in China from 1950 to 2016. Landslides 15:2357-2372. https://doi. org/10.1007/s10346-018-1037-6

Malone AW (2012) The story of quantified risk and its place in slope safety policy in Hong Kong. In: Glade T, Anderson M, Crozier MJ (eds) Landslide hazard and risk. Wiley, New York

Monsieurs E, Kirschbaum D, Thiery W et al (2017) Constraints on landslideclimate research imposed by the reality of fieldwork in Central Africa. In: 3rd North America symposium on landslides. Landslides Putting experience, knowledge and emerging technologies into practice, pp 158-168

Mukhlisin M, Idris I, Salazar AS et al (2010) GIS based landslide hazard mapping prediction in Ulu Klang, Malaysia. ITB J Sci 42A:163-178. https://doi.org/ 10.5614/itbj.sci.2010.42.2.7

Ng KY (2012) Rainfall-induced landslides in Hulu Kelang area. Malays Ecol Econ 1:32. https://doi.org/10.1017/CBO9781107415324.004

Pacheco M, Pinhel A, Einsfeld R (2002) Assessment of mortality in landslides in single and multiple slopes. Manag Inf Syst 31:681-690

Pereira S, Zêzere JL, Quaresma I (2017) Landslide societal risk in Portugal in the period 1865-2015. In: Sassa K, Mikoš M, Yin Y (eds) Advancing culture of living with landslides. Springer, Cham, pp 491-499. https://doi.org/10. 1007/978-3-319-59469-9

Petley D (2012) Global patterns of loss of life from landslides. Geology 40:927-930. https://doi.org/10.1130/G33217.1

PLANAT (National Platform for Natural Hazards) (2014) Strategy protection against natural hazards. Security level for natural hazards. Federal Office for the Environment FOEN, Bern

Porter M, Holm K, Jakob M, McDougall S (2017) Risk-based landslide safety assessments in Canada. In: 3rd North American symposium on landslides, Roanoke, Virginia, USA, pp 574-584

Pradhan B, Lee S (2010) Delineation of landslide hazard areas on Penang Island, Malaysia, by using frequency ratio, logistic regression, and 
artificial neural network models. Environ Earth Sci 60:1037-1054. https://doi.org/10.1007/s12665-009-0245-8

Raetzo H, Lateltin O, Bollinger D, Tripet JP (2002) Hazard assessment in Switzerland — codes of practice for mass movements. Bull Eng Geol Environ 61:263-268. https://doi.org/10.1007/s10064-002-0163-4

Roslee R (2019) Landslide risk management (LRM): towards a better disaster risk reduction (DRR) programme in Malaysia. ASM Sci J 12:70-81

Rossi M, Guzzetti F, Salvati P et al (2019) A predictive model of societal landslide risk in Italy. Earth Sci Rev 196:102849. https://doi.org/10.1016/j. earscirev.2019.04.021

Roy S, Kshirsagar R (2020) Development of risk acceptance criteria in the Indian context. Process Saf Environ Prot 148:358-369. https://doi.org/ 10.1016/j.psep.2020.10.021

Sättele M, Bründl M, Dorf D (2016a) Towards the evaluation of human factors in avalanche early warning systems. In: International snow science workshop, Breckenridge, Colorado, pp 222-229

Sättele M, Bründl M, Straub D (2016b) Quantifying the effectiveness of early warning systems for natural hazards. Nat Hazards Earth Syst Sci 16:149-166. https://doi.org/10.5194/nhess-16-149-2016

Sättele M, Krautblatter M, Bründl M, Straub D (2016c) Forecasting rock slope failure: how reliable and effective are warning systems? Landslides 13:737-750. https://doi.org/10.1007/s10346-015-0605-2

Saw JL, Wardman M, Wilday J et al (2009) Societal risk: initial briefing to societal risk technical advisory group. Hse Rr703, pp 1-74

Schuster RL (1996) Socioeconomic significance of landslides. Spec Rep Nat Res Counc Transp Res Board 247:12-35

Schuster RL, Highland LM (2001) Socioeconomic impacts of landslides in the Western Hemisphere. US Department of the Interior, US Geological Survey, Denver

Sidle RC, Ochiai H (2006) Processes, prediction, and land use American Geophysical Union. AGU Books Board. American Geophysical Union, Washington

Song QH, Liu DS, Wu YX (2007) Study on the acceptable and tolerable risk criteria for landslide hazards in the mainland of China. In: ISGSR2007 first international symposium on geotechnical safety and risk. Shanghai Tongji University, China, pp 363-374

Strouth A, McDougall S (2020) Societal risk evaluation for landslides: historical synthesis and proposed tools. Landslides 18:1071-1085. https://doi. org/10.1007/s10346-020-01547-8

Strouth A, McDougall S (2021) Historical landslide fatalities in British Columbia, Canada: trends and implications for risk management. Front Earth Sci 9:1-8. https://doi.org/10.3389/feart.2021.606854

Sui H, Hu R, Gao W et al (2020) Risk assessment of individual landslide based on the risk acceptable model: a case study of the Shiyantan landslide in Mayang County, China. Hum Ecol Risk Assess 26:2500-2519. https://doi. org/10.1080/10807039.2019.1710461

Sultana N (2020) Analysis of landslide-induced fatalities and injuries in Bangladesh: 2000-2018. Cogent Soc Sci 6:2000-2018. https://doi.org/10.1080/ 23311886.2020 .1737402

Tappenden KM (2014) The district of North Vancouver's landslide management strategy: role of public involvement for determining tolerable risk and increasing community resilience. Nat Hazards 72:481-501. https:// doi.org/10.1007/s11069-013-1016-0

Tonkin \& Taylor Ltd (2015) Supplementary risk assessment debris flow hazard matata, Bay of Plenty. Whakatane District Council, 29115.2000

Town of Canmore (2015) Cougar creek long-term mitigation option analysis summary report. Town of Canmore, Canada

Trbojevic VM (2005) Risk criteria in EU. In: Advances in safety and reliabilityproceedings of European safety and reliability conference ESREL 2005, vol 2, pp 1945-1952

Tsao T, Lo W, Chen C et al (2011) The evaluation of debris flow risk management effectiveness in Taiwan-using F-N curve as a tool. Geophys Res Abstr 13:5538

Turner AK (2018) Social and environmental impacts of landslides. Innov Infrastruct Solut 3:25-27. https://doi.org/10.1007/s41062-018-0175-y

UNISDR (2015) Sendai framework for disaster risk reduction 2015-2030. UNISDR, Geneva

Van Westen CJ, Alkema D, Damen MCJ et al (2011) Multi-hazard risk assessment. Distance Education Course Guide Book. United Nations University-ITC School on Disaster Geoinformation Management (UNU-ITC DGIM), Tokyo, Japan
Vranken L, Van Turnhout P, Eeckhaut MVD, Vandekerckhove L, Poesen J (2013) Economic valuation of landslide damage in hilly regions: a case study from Flanders, Belgium. Sci Tot Environ 447:323-336. https://doi.org/10. 1016/j.scitotenv.2013.01.025

Vrijling JK, van Gelder PHAJM (1997) Societal risk and the concept of risk aversion. Adv Saf Reliab 1:45-52. https://doi.org/10.1016/b978-00804 2835-2/50005-9

Winter MG, Bromhead EN (2012) Landslide risk: some issues that determine societal acceptance. Nat Hazards 62:169-187. https://doi.org/10.1007/ s11069-011-9987-1

Winter MG, Wong JCF (2020) The assessment of quantitative risk to road users from debris flow. Geoenviron Disasters 7:1-19. https://doi.org/10.1186/ s40677-019-0140-x

Winter MG, Shearer B, Palmer D, Sharpe J (2018) Assessment of the economic impacts of landslides and other climate-driven events. Published Project Report PPR 878. Transport Research Laboratory, Wokingham

Winter MG, Peeling D, Palmer D, Peeling J (2019) Economic impacts of landslides and floods on a road network. Acta Univ Carolinae Geogr 54:207-220. https://doi.org/10.14712/23361980.2019.18

Wong HN (2005) Landslide risk assessment for individual facilities. In: Hungr O, Fell R, Couture R, Eberhardt E (eds) Landslide risk management, proceedings, Vancouver conference. Taylor and Francis Group, London, pp 237-296

Wong HN, Ko FW (2005) Landslide risk assessment-application and practice. Geotechnical Engineering Office, Civil Engineering and Development Department, Hong Kong

Wong HN, Ko FWY, Hui THH (2006) Assessment of landslide risk of man-made slopes in assessment of landslide risk of man-made slopes in Hong Kong. GEO Report No. 191. Homantin, Kowloon, Hong Kong

World Bank (2018) Population density (people per sq. km of land area) | Data. https://data.worldbank.org/indicator/EN.POP.DNST. Accessed 7 July 2021

World Bank (2020) WDI—-the world by income and region. World by income 2018. World Bank, Washington

Wu S, Lei Y, Cui P et al (2020) Chinese public participation monitoring and warning system for geological hazards. J Mt Sci 17:1553-1564. https:// doi.org/10.1007/s11629-019-5933-6

Yifru J, Westen DCJ van, Hack DHRGK (2015) National scale landslide hazard assessment along the road corridors of Dominica And Saint Lucia. Master's thesis, University of Twente

Zhang Y, Wu W, Qin Y et al (2020) Mapping landslide hazard risk using random forest algorithm in Guixi, Jiangxi, China. ISPRS Int J Geo Inf 9:1-15. https://doi.org/10.3390/ijgi9110695

\section{Publisher's Note}

Springer Nature remains neutral with regard to jurisdictional claims in published maps and institutional affiliations.

\section{Submit your manuscript to a SpringerOpen ${ }^{\circ}$ journal and benefit from:}

- Convenient online submission

- Rigorous peer review

- Open access: articles freely available online

- High visibility within the field

- Retaining the copyright to your article

Submit your next manuscript at $\boldsymbol{\nabla}$ springeropen.com 